\title{
The examination of the relationship between the speech anxiety and speaking skill attitudes of middle school students and the opinions of teachers on speech anxiety
}

\author{
Keziban Tekşan a* (iD), Hasan Hüseyin Mutlu ${ }^{\text {b (iD), Enes Çinpolat }}{ }^{\text {(iD) }}$ \\ ${ }^{a}$ Ordu University, Faculty of Education, Ordu, 52000, Turkey \\ ${ }^{b}$ Ordu University, Faculty of Education, Ordu, 52000, Turkey \\ ${ }^{b}$ Ordu University, Faculty of Education, Ordu, 52000, Turkey \\ APA Citation:
}

Tekşan, K., Mutlu, H. H., \& Çinpolat, E. (2019). The examination of the relationship between the speech anxiety and speaking skill attitudes of middle school students and the opinions of teachers on speech anxiety. Journal of Language and Linguistic Studies, 15(4), 00-00.

Submission Date:15/10/2019

Acceptance Date:11/11/2019

\begin{abstract}
In this study, the relationship between the speech anxiety and speaking skill attitudes of middle school students and the reasons for students' speech anxiety, the conditions in which speech anxiety is observed, and the solutions of teachers were scrutinized. In the research, mixed method was used since it allows more in-depth examination. In this method, the sequential explanatory design was used. The first stage of the study was conducted with 546 middle school students in order to determine the relationship between the speech anxiety and speaking skill attitudes of middle school students. The second stage of the study was conducted with 20 teachers working in the same school that students are studying in order to determine the conditions that speech anxiety is observed, the reasons of these conditions, and the activities that teachers perform in order to eliminate speech anxiety with the opinions of teachers. The data collection tools of the study consist of personal information form, speech anxiety scale, speaking skill attitudes scale and interview form. In the analysis of the data, the IBM SPSS and MAXQDA 12 programs were used. According to the results of the study, there was a negative significant relationship between the speech anxiety and speaking skill attitudes of the students. Furthermore, teachers stated that they observe speech anxiety in students when they are speaking in front of a group, the reasons of speech anxiety are mostly the fear of being mocked and lack of self-confidence and that they create more appropriate speech subjects and anxiety environments in order to eliminate speech anxiety.
\end{abstract}

C 2019 JLLS and the Authors - Published by JLLS.

Keywords: Speech; speech skills; speech anxiety; middle school students

\section{Introduction}

Language is an important phenomenon that belongs to human beings in the formation of culture, scientific developments and communication (Okur, Sügü̈mlü \& Göçen, 2013). A healthy person is born with linguistic competence and starts to speak within the natural process. Speaking is the most natural and common communication tool that individuals use in expressing themselves and fulfilling their

\footnotetext{
* Corresponding author. Tel.: +90-452-226-5200 (5531)

E-mail address: keziban@odu.edu.tr
} 
needs. Since the communication between individuals mostly takes place with speaking, spoken language forms the basis of social life (Temizkan, 2009). "The activity that affects and leads to the success of humans in professional, educational and private life is speaking, which can be identified as verbal communication that takes place between individuals and individuals-society." (Kurudayığlu, 2003, p. 288). Although the four linguistic skills develop in touch with each other (Yalçın, 2018), speaking skill is the starting point of the other language skills (Özbay, 2003). Furthermore, speaking is a learning field. "Children learn various information by speaking and develop both speaking and mental skills." (Güneş, 2014, p. 5). "The ornament of the mind is language and the ornament of the language is the word; the ornament of a person is the face and the ornament of the face is eyes." (Arat, 1974, p. 31). As also emphasized in Kutadgu Bilig, speaking is the manifestation of a person. "Speaking is the most important indicator of completely knowing a language and, at the same time, it is the most essential condition in achieving success in school for students." (Doğan, 2009, p. 186). "Humans can sustain their lives without reading and writing, however, it is not possible for them to live without speaking and listening." (Topçuoğlu-Ünal \& Özden, 2012, p. 136).

Speaking skill, which is crucial in almost every field of social life (Yalçın, 2018), is included in the special purposes of Turkish as "providing students to use Turkish consciously, accurately, and attentively in accordance with the speaking and writing rules and providing them to express their feelings, ideas, opinions or arguments efficiently and apprehensibly in an oral or written way". In the curriculum, acquisitions about the speaking skill were determined from the first grade to eighth grade. As can be seen, the ability to express the feelings and opinions in accordance with the Turkish rules are acquired to the students in Turkish and this responsibility belongs to Turkish education above all.

However, studies which indicate that students do not possess the desired speaking skill, reveal our insufficiency on this subject (Arhan, 2007; Arslan, 2012; Ceran, 2012; Dülger, 2011; Topçuoğlu-Ünal \& Özer, 2017; Sargin, 2006). Students cannot express themselves clearly and accurately (Yelok \& Sallabaş, 2009) and encounter several problems in schools and social environments whether they are prepared or not (Demir \& Melanlığlu, 2014, p. 108). While Doğan (2009), who states that the education of speaking skill is one of the subjects that is neglected in Turkish education and the results of ignoring this skill manifest itself in each stage of education, from primary school to higher education, indicates that "The traditional family structure of our society does not allow children to speak and there are conditions in which students are not allowed to speak more than necessary in order to maintain discipline in classroom environment". Aksakal (2002, p. 35) states that mother tongue education is conducted textfocused and thus, speaking skill is not handled sufficiently in Turkish. Akyol (2012, p. 23) believes that the problem originates from the teachers who think that students acquire the speaking skill before they come to the school and it is not necessary to put emphasis on this skill. In a study in which the speaking problems that were observed in the second grade of primary school students were evaluated in accordance with the opinions of Turkish teachers (Topçuoğlu-Ünal \& Degeç, 2012, p. 742), it was determined that the most remarkable speaking problem observed in the students was embarrassment/excitement with the rate of $31 \%$. In the same study, teachers pointed out the approaches of families as the reason for lack of self-confidence. The conducted studies support the opinions of teachers and consider speech anxiety as the leading speaking problem (Demir \& Melanlıoğlu, 2014; Kardaş \& Şahin, 2016; Özdemir, 2018).

Speech anxiety is regarded as a strong feeling that can be encountered in every field, ranging from daily life to professional life and individuals feel anxious when speaking in front of a group (Akkaya, 2012; Arslan, 2012; Gürzap, 2010). "Studies revealed that the fear of speaking in front of a group is observed more than the fears of test, height, and even death." (Maviş, 2013, p. 64). For this reason, studies on speech anxiety gained momentum. However, these studies mainly focus on the anxiety conditions of foreign students on the education of Turkish as a foreign language and the speech anxiety 
levels of prospective Turkish teacher (Baki \& Kahveci, 2017; Baki \& Karakuş, 2015; Katrancı \& Kuşdemir, 2015; Lüle-Mert, 2015; Melanlığlu \& Demir, 2013; İşcan \& Karagöz, 2016; Özkan \& Kınay, 2015; Özdemir, 2018; Sallabaş, 2012; Sevim, 2014; Sevim, 2012; Suroğlu-Sofu, 2012; Temiz, 2013; Temiz, 2015). In certain studies, the effects of different methods on speech anxiety were examined (Bulut, 2015; Hasırc1, 2018).

There is a limited number of studies on the speech anxiety of middle school students (Demir \& Melanlıoğlu, 2014; Kavruk \& Deniz, 2015; Keşaplı \& Çifci, 2017; Sevim \& Gedik, 2014). It is of great importance to determine the speech anxiety conditions of middle school students. Because, the acquisitions to use words in accordance with their meaning; to perform unprepared speeches; to speak about a specific subject; to apply speaking strategies; to participate in-class discussions; to perform prepared speeches; to efficiently use the body language in speeches; to use the appropriate transition and conjunction expressions, and to use the Turkish versions of the words that were taken from foreign languages are taught to the students from the beginning of primary school to the end of the middle school. In this context, the speech anxiety conditions of students would directly affect the achievement of students both in Turkish and in other lessons. Additionally, it is important for teachers to acknowledge the speech anxiety conditions of students.

Speech anxiety is defined as "the anxiety that causes physical symptoms such as the excitement of individuals in the obligation of public speaking or avoiding to speak with other people, not being able to express themselves sufficiently, sweating, blushing, and the acceleration of heartbeat" (Keşaplı \& Çifci, 2017, p. 465). Mental, physiological, emotional, and hereditary-biological reasons may cause speech anxiety, and speech anxiety creates many negative cognitive, physical, and behavioral conditions in individuals. "Problems such as; forgetting what to say, questioning what they say in a conversation while contemplating on whether or not they are expressing themselves accurately and efficiently, and not being able to focus on the conversation are observed cognitively; over sweating, thrilling, shaking hands, dry mouth, and blushing are observed physically, and avoiding eye contact with the listener, making exaggerated movements, not being able to stand firmly, speaking briefly, cluttering, and giving pauses are observed behaviorally. It can be stated that individuals who experience these problems cannot efficiently convey their emotions, opinions, and knowledge." (Özdemir, 2018). These individuals do not want to speak, avoid speaking or speak obtrusively (Kınay \& Özkan, 2014). Students who have a high level of speech anxiety avoid communicating with their teachers and friends, don't express their emotions and opinions, and even, don't respond to the questions that they know and don't communicate with anybody. Additionally, the low or middle level of speech anxiety is defined as "a strong motivation that encourages to behave creative, enthusiastic, and positive" (Maviş, 2013, p. 64).

It is required for Turkish teachers to know the speech anxiety conditions of students and behave accordingly so that they can teach the four basic skills to students. As mentioned above, the ability to express the emotions and opinions in accordance with the rules of Turkish is taught to the students in Turkish course. Speaking skill improves with practice, like other skills. Determining the speech anxiety conditions of students would guide the parents and educators to find ways for behaving accordingly and reducing the speech anxiety levels that negatively affect speaking. Although there is an increasing number of studies on this subject, they are not enough. In this context, it is considered that this study would contribute to the literature. 


\section{Method}

\subsection{Study Design}

Mixed method design was used in the study since it allows more in-depth examination. Mixedmethod design is defined as using two or more analysis or data collection methods in the same research (Greene, Krayder \& Mayer, 2005). In this study, the sequential explanatory design was used. Since the mixed method reveals various aspects of an incident, it is frequently used in educational studies (Silverman, 2000). This research design starts with the collection and analysis of quantitative data which corresponds to the research question with primary priority. Then, the second stage is the collection and interpretation of the qualitative data. The second stage, in which the qualitative stage is conducted, is performed by monitoring the results of the first stage (Creswell \& Plano Clark, 2007). In this research, qualitative data was collected and interpreted based on the data that was obtained in the quantitative stage.

\subsection{Participants}

The first stage of the study was conducted in three randomly selected middle schools located in the central district of a province in the northern part of Turkey in the spring semester of 2018-2019 in order to determine the relationship between the speaking anxieties and speaking skill attitudes of middle school students. The study group of the first stage consists of a total of 546 voluntary middle school students (5th, 6th, 7th, 8th grades) as 282 female and 264 male. Furthermore, necessary permissions were taken from the Provincial Directorate of National Education where the study was conducted.

The second stage of the study was conducted with 20 voluntary teachers, 12 male and 8 female, who were working in the same school $\mathrm{s}$ in order to determine the opinions of teachers on the conditions in which speech anxiety is observed and to determine the basis of these conditions and the activities conducted to eliminate speech anxiety. The range of the teachers' professional experience was between 8 to 24 . The range of the teachers' age was between 33 to 48 . The teachers were coded as P1, P2, P3...

\subsection{Instruments}

Personal Information Form: In the first stage of the study, students were asked questions about their gender, grade, age, and whether or not they use bookcase in their homes in the personal information form developed by the researchers. In the second stage, teachers were asked questions on their gender, age, and period of duty.

Speech Anxiety Scale: The scale was developed by Keşaplı and Çifci (2017) in their study titled "Speech Anxiety of Middle School Students" and reliability and validity analyses were conducted. The scale consists of 3 sub-dimensions with 23 items in a 5-point Likert type. While the Cronbach Alpha value, which is the internal consistency coefficient of the scale, was determined as .91 in the study in which the scale was developed, it was determined as .83 in the present study.

Speaking Skill Attitude Scale: The scale was developed by Topçuoğlu-Ünal and Özer (2017) in their study titled "Speaking Skill Attitude Scale: Reliability and Validity Study" and the reliability and validity analyses were conducted. The scale consists of 2 sub-dimensions with 27 items in a 5-point Likert type. While the Cronbach Alpha value, which is the internal consistency coefficient of the scale, was determined as .81 in the study in which the scale was developed, it was determined as .85 in the present study.

Interview Form: Written interview form was used for the second stage of the study. In the interview form, there were three questions about the conditions that teachers observed speech anxiety in students, 
the reasons for these conditions, and the activities that are conducted to eliminate speech anxiety. 3 field experts and 3 Turkish teachers were consulted while developing this form and the questions were finalized in accordance with their opinions.

\subsection{Data collection procedures}

In the first stage of the study, a suitable period of time was determined by examining the weekly course schedule of the students in order to collect the data of the study. First, middle school students were disclosed about the scales and how to mark them. Then, students were asked to fill out the speech anxiety scale and speaking skill attitudes scale at their convenience. Time limit was not applied while students are filling out the scales and it was waited until all the students completed the scale.

Pre-interviews were conducted with Turkish students who participated in the second stage of the study and explanations were made about the content, purpose, and importance of the study in these interviews. The questions of teachers were answered, and it was explained that their opinions are important and required for determining and eliminating the problems on the subject. It was asked whether or not they want to share their opinions written or verbally and since they decided to share their opinions by writing and an observation process was required for determining the conditions of students, the forms were given to the teachers and were asked to complete them in two weeks. After this period, the forms were collected from them.

\subsection{Data analysis}

In the analysis of the quantitative data, within the IBM SPSS 24.0 statistical program, descriptive research, one-way ANOVA test, and independent samples t-test were used since the data demonstrated normal distribution. It was observed that the skewness and kurtosis coefficients of speech anxiety scale and speaking skill attitudes scale scores were between -2 and +2 (Skewness $=.285$, Kurtosis $=.160$; Skewness $=-.302$, Kurtosis $=.112$ ). It can be stated that when the skewness and kurtosis coefficient approaches zero, the distribution becomes normal (Tabachnick \& Fidell, 2007; Field, 2013). In the literature, the skewness and kurtosis coefficients of -2 to +2 are considered sufficient for assuming the distribution to be normal (George \& Mallery, 2003). In this research, bootstraps (1000) were made, and coefficient and confidence intervals were determined.

The data obtained from the written interview form was transferred to MAXQDA 12 qualitative data analysis program and analyzed with the content analysis technique. The basic process conducted in the content analysis is to bring the similar data together within the framework of certain concepts and themes and to interpret this by editing in a way that the reader could easily understand (Yıldırım \& Şimşek, 2013). The categorical analysis was used among the content analysis techniques. In the categorical analysis, first, the data was coded. The codes are the symbols used for classifying or grouping the word groups and concepts related to the questions of the study (Robson, 2001). The themes were defined in the written interview questions, the coding was performed with three field experts. Quotations were given from the opinions of teachers on the emerged codes. The analyzed data was presented and interpreted with the visuals obtained from the program. 


\section{Results}

3.1. Findings on the Relationship Between the Speech Anxiety and Speaking Skill Attitudes of Middle School Students

Table 1. Findings on the gender variable

\begin{tabular}{|c|c|c|c|c|c|c|c|}
\hline & Gender & $N$ & $M$ & $S D$ & $d f$ & $t$ & $p$ \\
\hline \multirow{4}{*}{$\begin{array}{l}\text { SAS (SPEECH ANXIETY } \\
\text { SCALE) }\end{array}$} & Female & 282 & 55.11 & 13.52 & 544 & -.023 & .981 \\
\hline & Male & 264 & 55.14 & 13.48 & & & \\
\hline & Total & 546 & & & & & \\
\hline & Gender & $N$ & $M$ & $S D$ & $d f$ & $t$ & $p$ \\
\hline \multirow{3}{*}{$\begin{array}{l}\text { SSAS } \quad \text { (SPEAKING } \\
\text { ATTITUDES SCALE) }\end{array}$} & Female & 282 & 103.01 & 14.62 & 544 & 3.076 & $.002 *$ \\
\hline & Male & 264 & 99.13 & 14.82 & & & \\
\hline & Total & 546 & & & & & \\
\hline
\end{tabular}

$* \mathrm{p}<.05$

When Table 1 is examined, it can be seen that there is no significant difference $\left(t_{(544)}=-.023, p>\right.$ $.05)$ between female and male students in terms of speech anxiety. But it can be observed that there is a significant difference $\left(t_{(544)}=3.076, p<.05 ; d=.26\right)$ in favor of female students in speaking skill attitudes. It can be stated that the speaking skill attitudes are higher in female students $(M=$ $103.01, S E=.87)$ than in male students $(M=99.13, S E=.91)$.

Table 2. Findings on the variable of possessing a bookcase

\begin{tabular}{|c|c|c|c|c|c|c|c|}
\hline & Bookcase & $N$ & $M$ & $S D$ & $d f$ & $t$ & $p$ \\
\hline \multirow{4}{*}{$\begin{array}{l}\text { SAC } \quad \text { (SPEECH } \\
\text { ANXIETY SCALE) }\end{array}$} & Possessed & 303 & 53.88 & 13.87 & 544 & -2.425 & $.016^{*}$ \\
\hline & Not Possessed & 243 & 56.68 & 12.86 & & & \\
\hline & Total & 546 & & & & & \\
\hline & Bookcase & $N$ & $M$ & $S D$ & $d f$ & $t$ & $p$ \\
\hline \multirow{3}{*}{$\begin{array}{l}\text { SSAS } \\
\text { SKILL } \\
\text { SCALE) }\end{array}$} & Possessed & 303 & 102.87 & 15.02 & 544 & 3.082 & $.002 *$ \\
\hline & Not Possessed & 243 & 98.96 & 14.34 & & & \\
\hline & Total & 546 & & & & & \\
\hline
\end{tabular}

$* \mathrm{p}<.05$

When Table 2 is examined, a difference was observed in the speech anxiety and speaking skill attitudes $\left(t_{(544)}=-2.425, p<.05 ; d=.20 ; t_{(544)}=3.082, p<.05 ; d=.26\right)$ between the students who possess bookcase in their home and those who don't possess. Accordingly, it can be stated that speech anxiety was lower in students who possess bookcase in their home $(M=53.88, S E=.79)$ than 
those who don't $(M=56.68, S E=.82)$. Furthermore, it can be stated that speaking skill attitudes was higher in students who possess bookcase in their home $(M=102.87, S E=.86)$ than those who don't $(M=98.96, S E=.91)$.

Table 3. Findings on the variable of the grade level (speech anxiety)

\begin{tabular}{|c|c|c|c|c|c|c|}
\hline & Sum of Squares & $d f$ & Mean Square & $F$ & $p$ & $\begin{array}{l}\text { Significant } \\
\text { Difference }\end{array}$ \\
\hline Between Groups & 2092.991 & 3 & 697.664 & 3.892 & $.009 *$ & $\begin{array}{l}6^{\text {th }} \text { grade - } \\
8^{\text {th }} \text { grade }\end{array}$ \\
\hline Within Groups & 97162.776 & 542 & 179.267 & & & \\
\hline Total & 99255.767 & 545 & & & & \\
\hline
\end{tabular}

A significant difference $\left(F_{(3,542)}=3.892, p<.05\right)$ can be observed in the speech anxiety of students according to their grades. According to the Tukey HSD post hoc test, which was conducted in order to determine this difference, it can be stated that the speech anxiety levels of $6^{\text {th }}$ grade $(M=57.78$, $S D=12.39)$ students were statistically higher than $8^{\text {th }}$-grade students $(M=52.28, S D=14.10)$.

Table 4. Findings on the variable of the grade level (speaking skills attitudes)

\begin{tabular}{|c|c|c|c|c|c|c|}
\hline & Sum of Squares & $d f$ & Mean Square & $F$ & $p$ & $\begin{array}{l}\text { Significant } \\
\text { Difference }\end{array}$ \\
\hline Between Groups & 2179.997 & 3 & 697.664 & 3.344 & $.019 *$ & $\begin{array}{l}5^{\text {th }} \text { grade - } \\
7^{\text {th }} \text { grade }\end{array}$ \\
\hline Within Groups & 117779.974 & 542 & 179.267 & & & \\
\hline Total & 119959.971 & 545 & & & & \\
\hline
\end{tabular}

As can be seen in Table 4, the speaking skill attitudes of students demonstrate a significant difference $\left(F_{(3,542)}=3.344, p<.05\right)$ according to their grades. According to the Tukey HSD post hoc test, which was conducted in order to determine this difference, it can be stated that the speech anxiety levels of $5^{\text {th }}$ grade students $(M=104.10, S D=13.15)$ were statistically higher than $7^{\text {th }}$-grade students $(M=$ 98.66, $S D=15.39)$.

Table 5. Relationship between the study variables

\begin{tabular}{lll}
\hline Variables & 1 & 2 \\
\hline SAS (1) & 1 & \\
\hline SSAS (2) & $-.48^{* *}$ & 1 \\
\hline Mean & 55.13 & 101.13 \\
\hline SD & & 14.83 \\
\hline
\end{tabular}


Note. $k=1000, * \mathrm{p}<.05, * * \mathrm{p}<.01 . \mathrm{N}=546$; SD: Standard Deviations; SAS: Speech Anxiety Scale. SSAS: Speaking Skill Attitudes Scale.

When Table 5 is examined, it can be observed that there was a negative significant relationship $(r=$ $-.48, p<.01 ; 95 \% \mathrm{CI}=-.51,-.41)$ between the speech anxiety and speaking skill attitudes of students. Accordingly, it can be concluded that as the speech anxiety levels of students increase, their speaking skill attitudes decrease.

It was decided to conduct a simple linear regression analysis in order to determine on what level speech anxiety predicts speaking skill attitudes. It is necessary to ensure that a range of preconditions is met, before conducting the regression analysis. Firstly, two-way correlations between the variables were investigated and it was assured that there wasn't a multi-collinearity. In line with this purpose, the Durbin-Watson value was investigated in the auto-correlation condition and it was concluded that the obtained value (1.78) was within normal limits (Field, 2013). Secondly, the tolerance value of the variance ratio that could not be explained by the independent variable (1-R2) and the variance inflation factor (VIF) were investigated. Since the tolerance value $(1-\mathrm{R} 2=1.00)$ was higher than .20 and the variance inflation factor $(\mathrm{VIF}=1.0)$ was lower than 10 , it was concluded there wasn't a problem of multicollinearity (Field, 2013).

As a result of the simple linear regression analysis, which was conducted after the necessary preconditions were provided, it was determined that writing motivation explained the $23.2 \%$ of the total variance of writing success $\left(F_{(1,544)}=164.58, p<.001\right)$. The negative effect of speech anxiety to the regression model was significant $(\beta=-.48, p<.001 ; 95 \% C I=-.61,-.45)$.

Table 6. The Predictor of Speaking Skill Attitudes

\begin{tabular}{cccccc}
\hline & $B$ & $S E$ & $\beta$ & $t$ & $p$ \\
\hline Fixed & 130.670 & 2.369 & & 55.169 & $<.001$ \\
SAS & -.537 & .042 & -.482 & -12.829 & $<.001$ \\
\hline
\end{tabular}

Note. $k=1000, R^{2}=.23, \Delta R^{2}=.23, p<.001$, SAS: Speech Anxiety Scale

\subsection{Findings on the Opinions of Teachers on Speech Anxiety}

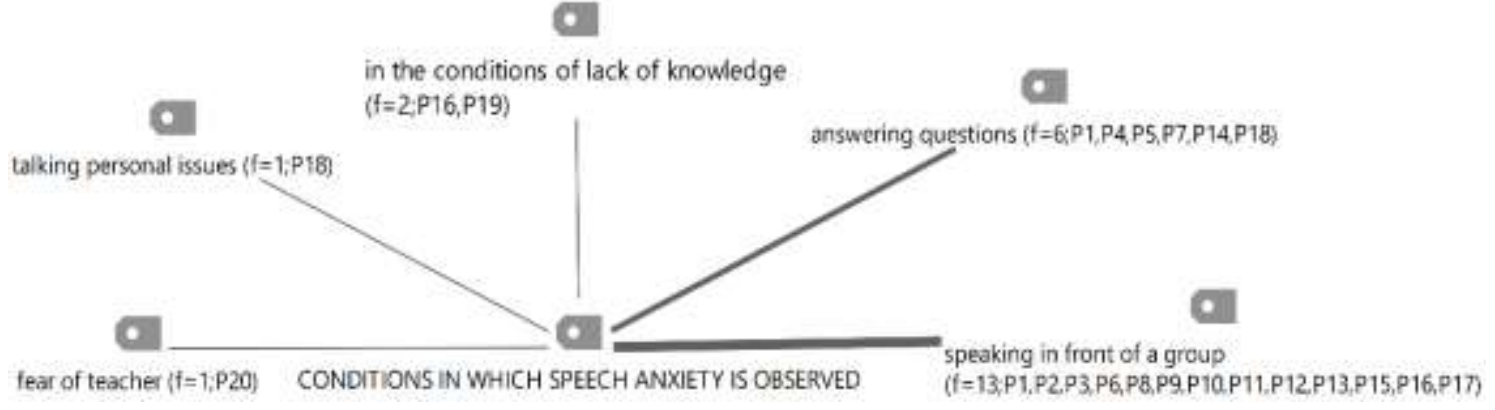

Figure 1. Findings on the conditions in which speech anxiety is observed.

Figure 1 demonstrates the conditions in which Turkish teachers observed speech anxiety in students. Accordingly, teachers drew attention to five conditions; speaking in front of a group (13), answering questions (6), in the conditions of lack of knowledge (2), talking personal issues (1), fear of teacher (1). Direct quotations from the opinions about the codes were presented below. 
Speaking in front of a group: Speech anxiety is mostly observed when my students appear before a group and when they are in the limelight (P3) when they are asked to answer the questions in front of a group, when they are required to perform a speech in a crowded environment or to perform a long speech (P12). I observe affrightment when they are speaking in-class environment in front of a group (P17).

Answering the questions: When I receive answers to the questions (P1). When I ask a question to a student who did not raise his/her hand, he/she gets excited (P14).

In the conditions of lack of knowledge: Furthermore, they feel anxious and excited when their homework is not done completely (P16).

Talking personal issues: When they make certain explanations about themselves (P18).

Fear of teacher: Students don't speak when I demonstrate strict temperament (P20).

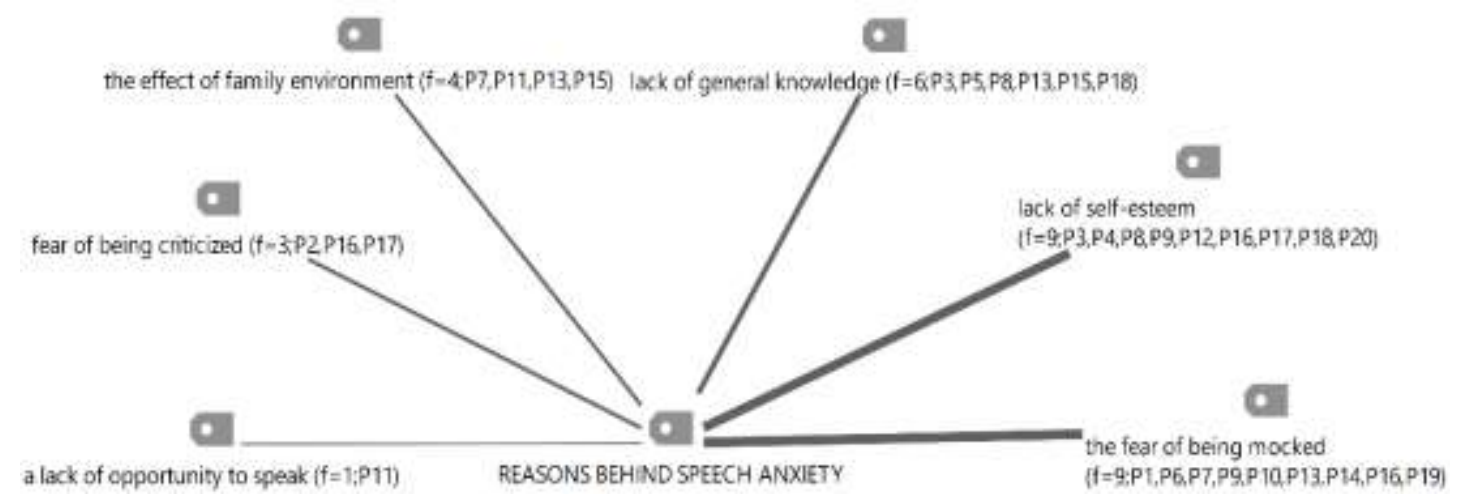

Figure 2. Findings regarding the reasons behind speech anxiety

Figure 2 displays the reasons behind the cases where Turkish teachers observe speech anxiety in their students. According to this, the teachers listed the fear of being mocked (9), lack of self-esteem (9), lack of general knowledge (6), the effect of family environment (4), fear of being criticized (3), a lack of opportunity to speak (1) as the situations that can lead to speech anxiety. Direct quotations from the comments related to the codes were presented below.

The fear of being mocked: The fear of being ridiculed, the thought of being laughed at by friends (P9). The thought of being laughed at (P10).

Lack of self-esteem: The thought of not being able to express oneself (P4). Reluctance to speak in public, insecurity (P12).

Lack of general knowledge: I think there are two main causes: Lack of knowledge on the subject and lack of self-esteem. In both of these cases, the students' fear of saying something wrong, their concern regarding the perception ofthe listeners and a lack of experience in engaging in healthy communication lead to these reasons (P3).

The effect of the family environment: Children are being criticized by their family, environment, etc. constantly, ridiculed for various reasons or brought up by an excessively perfectionist family (P7).

Fear of being criticized: I consider the fear of being criticized by their friends and teachers as a reason for anxiety (P16). 
A lack of opportunity to speak: Not being given enough opportunity to speak (P11).

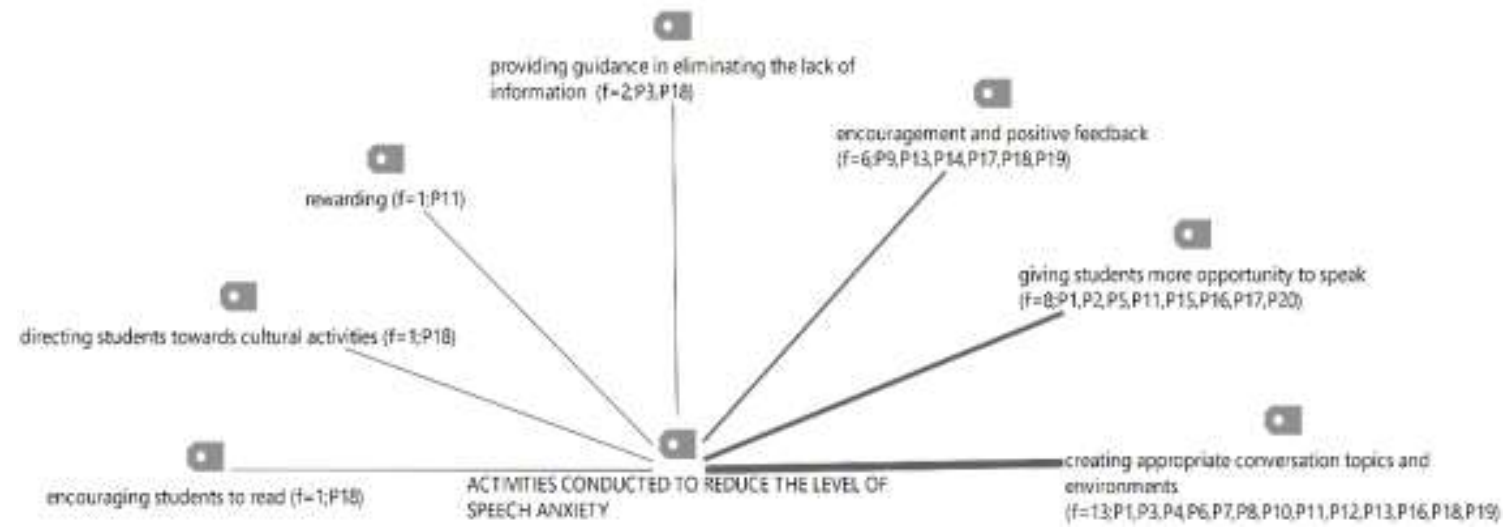

Figure 3. Findings regarding the activities conducted to reduce the level of speech anxiety

Figure 3 displays the activities conducted by Turkish students to reduce the speech anxiety levels of their students. According to this, the teachers stated that they conducted the following activities to reduce speech anxiety: creating appropriate conversation topics and environments (13), giving students more opportunity to speak (8), encouragement and positive feedback (6), providing guidance in eliminating the lack of information (2), rewarding (1), directing students towards cultural activities (1), encouraging students to read (1). Direct quotations from the comments related to the codes are presented below.

Creating appropriate conversation topics and environments: By adding subjects that would draw the attention or interest of them with activities (P6). A comfortable class environment: To make them feel safe, to motivate them in terms of self-confidence. Speech practices in-class environment in order to bring them out of their shell (P12). I provide a relaxing environment and give positive feedbacks (P4).

Giving students more opportunity to speak: I make sure that each student performs a speech at least one time throughout the semester (P11). I provide them to be active by giving opportunity to speak (P20).

Encouragement and positive feedback: I encourage the students and after their speech, I thank them (P9). I encourage and thank them since they share their opinions (P13).

Providing guidance in addressing the lack of information: I guide and support them in accessing accurate resources in terms of eliminating the lack of knowledge. Because students feel more confident about the information of which they learn by researching and this situation decreases the anxiety of imperfect or wrong information (P3).

Rewarding: I give plus 10 points for the first speech and plus 5 points for each consecutive speeches to in-class performance of students.

Directing students towards cultural activities: Guiding students to artistic and cultural events (P18).

Encouraging students to read: Giving importance to reading books (P18). 


\section{Conclusion and Discussion}

In the present study, the relationship between the speech anxiety and speaking skill attitudes of middle school students was examined. Interviews were conducted with Turkish teachers and the conditions in which speaking anxieties of students are observed, the reasons behind them, and the activities conducted by teachers to eliminate the speech anxiety levels of students were examined.

The attitudes of the participating students towards their speech anxiety levels and speaking skills were examined based on the variable of gender. As a result of the study, there wasn't a significant difference between the speech anxiety levels of male and female students. However, it was observed that the attitudes of the female students towards speaking skills were higher than the male students. In the studies conducted by Boylu and Çangal (2015); Gedik (2015); Kardaş (2015); Katrancı and Kuşdemir (2015); Kavruk and Deniz (2015); Özkan and Kınay (2015); Sallabaş (2012); Şen (2017); Şen and Boylu (2015) and Tüzemen (2016), no significant relationship could be determined between the level of anxiety and the gender variable. In the study of Keşaplı and Çifci (2017) conducted with middle school students, it was determined that speech anxiety did not demonstrate a significant difference according to the gender variable. In the study conducted by Arslan (2018), the relationship between the speech anxiety and academic self-efficacy levels of middle school students was examined and a significant difference was determined in favor of female students in terms of the gender variable. In the study conducted by Sevim and Gedik (2014), it was observed that the speech anxiety scores of middle school students demonstrated a significant difference in favor of female students in terms of the gender variable. Based on the results of the study conducted by Baki and Karakuş (2015) on Turkish prospective teachers, it was determined that the speech anxiety scores of the prospective teachers demonstrated a significant difference in terms of the gender variable. When the studies are examined, it was observed that there were different conclusions in terms of the gender variable. However, it can be said that there is no significant difference between male and female students in terms of the gender variable in general.

According to the study results, the anxiety levels of the students that have a library at home were lower than the ones that do not and their attitudes towards speaking were higher as well. According to the teachers who participated in the study, one of the reasons behind speech anxiety is the lack of information and general knowledge. It was revealed in the study conducted by Y1lmaz and Okur (2017) that the lack of knowledge increases speech anxiety. Reading enriches an individual in terms of general knowledge and increases the overall level of knowledge. Spending time in libraries outside the classroom has great benefits for students such as gaining knowledge and acquiring reading habit (Çiftçi, 2007). An individual who is equipped with information and general knowledge will also have an increased level of self-esteem. The results of the study conducted by Kardaş (2015) support the results of the present study. In the study conducted by Kardaş (2015), it was observed that there was a significant relationship between the number of books read per year and speech anxiety. Accordingly, the results obtained in these studies support this study.

According to the study results, the speech anxiety levels of sixth-grade students were higher compared to the eighth-grade students. On the other hand, the speaking skill attitudes of fifth-grade students were higher compared to seventh-grade students. In the study conducted by Suroğlu-Sofu (2012), it was observed that the speech anxiety levels of second and fourth-grade prospective teachers demonstrated a significant difference while the anxiety levels of fourth-graders were lower. In the study conducted by Arslan (2018) on middle school students, speech anxiety levels were examined based on the grade variable and in parallel with the present study, a significant difference in favor of eighth-grade students was determined compared to sixth-grade students. In the study conducted with fourth-grade prospective teachers, Baki and Karakuş (2015) determined that the anxiety levels of second-grade prospective teachers were higher compared to fourth-grade prospective teachers. In Kardaş's study 
(2015), the anxiety levels of prospective teachers did not demonstrate a significant difference based on grade level. In a similar study (Keşaplı \& Çifci, 2017), there wasn't a significant difference in the anxiety levels of middle school students based on the grade variable. There wasn't a significant difference between the speech anxiety levels of middle school students and the grade variable in the study conducted by Kavruk and Deniz (2015). In general, there are significant differences in certain studies according to the grade level variable while others do not.

Data obtained in the present study revealed that the anxiety levels of middle school students had a negative effect on their speaking skills. The attitudes of the participating students towards their speaking skills decrease as their anxiety levels increase. Many studies revealed that high anxiety levels negatively affect other skills. In Arslan's study (2018), it was determined that the speech anxiety levels of middle school students decreased as their academic self-efficacy levels increased. In another study (Katrancı \& Kuşdemir, 2015), it was observed that the speaking anxieties of prospective teachers were high in the pre-test while their desire to speak in public was low. In the study conducted by İşcan and Karagöz (2016) with prospective teachers, it was observed that the speech anxiety levels of the participants were high. Based on this result, it can be stated that anxiety level negatively affects the attitude towards speaking.

Based on the results of the interviews conducted with the participating Turkish teachers, speech anxiety in students is generally observed while speaking in front of a group, answering questions, in cases where a lack of knowledge is in effect, in private subjects (speaking about themselves) and in cases where the teacher has a strict temperament. Based on the answers given by the participating teachers, it was revealed that speech anxiety occurs most often when speaking in public. In the study conducted by İşcan and Karagöz (2016) in which the speech anxiety levels of Turkish prospective teachers were examined, it was stated that the speaker-oriented anxiety levels of the students were high and that the factors affecting this situation consisted of a lack of self-esteem, inadequate practice in public speaking and the students feeling of inadequacy in terms of subject matter knowledge. In the study conducted by Akkaya (2012) with prospective teachers, it was determined that the most important reasons behind speech anxiety were "inability to speak in public, a lack of knowledge, inability to speak in personal relationships". Accordingly, the results obtained in these studies support this study.

The majority of the participating Turkish teachers stated the reason behind the speech anxiety observed in students as "the fear of being mocked". On the other hand, the participating teachers also stated the lack of self-esteem, lack of general knowledge, lack of experience, family environment, fear of being criticized, and a lack of opportunity to speak as the reasons behind speech anxiety. Similarly, the results of the present study, in the study conducted with Turkish teachers, Topçuoğlu-Ünal and Degeç (2012) listed the reasons behind the speaking problems faced by teachers as a lack of knowledge, the local dialect spoken in their family and inner circle, and anxiety in front of audiences. The results of the study conducted by Katranc1 (2014) support the teacher responses. In the study, it was determined that the self-efficacy perceptions of the prospective teachers in the eloquence, applying the rules of speech, editing speech content and speech evaluation sub-dimensions were high while their self-efficacy perceptions in the public speaking sub-dimension were moderate. In the study conducted by Arslan (2012) to determine the views of university students on public speaking, it was concluded that the majority of the participating students were reluctant towards taking part in events that require public speaking due to reasons such as the mocking behavior of listeners and teachers, lack of knowledge and self-esteem, fear of giving inaccurate or imperfect knowledge, shy temperament, not being used to speak in front of a group, having inadequate command of Turkish, inability to express oneself accurately and expression anxiety. Similar results have been observed in other studies on the subject. 
Based on the study results, the Turkish teachers stated that they created appropriate conversation topics and environments, attempted to give students more opportunity to speak, encouraged them and attempted to give positive feedback, provided guidance in addressing the lack of information, rewarded students, directed them towards cultural activities and encouraged them to read in order to reduce the speech anxiety levels of students. In the study conducted by Topçuoğlu-Ünal and Degeç (2012), the Turkish teachers stated that they attempted to solve the issues they faced by using methods and techniques such as giving exercises, reading, correcting mistakes, and appreciation. In the study conducted by Hasircı (2018), it was determined that peer and teacher feedback created a significant difference in reducing the anxiety levels of prospective teachers. Other studies in the literature also show similarities with the results obtained in this study.

\subsection{Suggestions}

Based on the obtained results, the following suggestions were developed:

- High attitudes of students towards speaking skills reduce speech anxiety. Based on this result, activities that improve the attitudes of students towards speaking can be included. The duration of simple speaking activities can be increased with fun, up-to-date and attentiongrabbing topics.

- Speech activities can be created using different methods such as micro-teaching in order to reduce the speech anxiety levels of students.

- Environments where students can express themselves freely can be created.

- Cultural activities can be increased with theater and drama activities.

\section{References}

Akkaya, A. (2012). Öğretmen adaylarının konuşma sorunlarına ilişkin görüşleri (The opinions of teacher candidates about speech problems). Mustafa Kemal Üniversitesi Sosyal Bilimler Enstitüsü Dergisi/Mustafa Kemal University Journal of Social Sciences Institute, 9(20), 405-420.

Aksakal, Ö. D. (2002). İşbirlikli öğrenme yönteminin anadili (Türkçe) eğitimine etkisi (Master’s thesis). Dokuz Eylül University, İzmir, Turkey.

Arat, R. R. (1974), Yusuf Has Hacib: Kutadgu Bilig [Book in Turkish]. Ankara: Türk Tarih Kurumu Yayınları.

Arhan, S. (2007). Öğretmen görüşlerine göre ilköğretim okullart ikinci kademede konuşma eğitimi (Ankara ili örneği) (Master's thesis). Gazi University, Ankara, Turkey.

Arslan, A. (2012). Üniversite öğrencilerinin "topluluk karşısında konuşma" ile ilgili çeşitli görüşleri (Ağrı İbrahim Çeçen Üniversitesi örneği) (Some opinions of the university students related to "giving a speech in front of public" (Ağrı İbrahim Çeçen University sample). Turkish Studies, 7(3), 221-231.

Arslan, A. (2018). Ortaokul öğrencilerinin okuma kaygıları ve akademik özyeterlik inançlarının çeşitli değişkenler açısından incelenmesi (Investigation of secondary school students' reading anxiety and academic self-efficacy beliefs in terms of various variables). E-Kafkas Ë̆itim Araştırmaları Dergisi/e-Kafkas Journal of Educational Research, 4(3), 30-44.

Baki, Y., \& Kahveci, G. (2017). Türkçe öğretmeni adaylarının konuşma kaygılarının etkili konuşma becerileri üzerindeki etkisi: bir yapısal eşitlik modellemesi (The effect on the effective speaking 
particulars of Turkish language teacher candidates 'speech: a structural equality modelling). Turkish Studies, 12(4), 47-70.

Baki, Y., \& Karakuş, N. (2015). A research on speech anxiety of prospective Turkish teachers. The Anthropologist, 21(1-2), 271-276.

Boylu, E., \& Çangal, Ö. (2015). Yabanci dil olarak Türkçe öğrenen bosna-hersekli öğrencilerin konuşma kaygilarinin çeşitli değişkenler açisindan incelenmesi (Turkish as a foreign language learner students in Bosnia and Herzegovina speaking anxiety investigation of different variables). Uluslararast Türkçe Edebiyat Kültür Eğitim (TEKE) Dergisi, 4(1), 349-368.

Bulut, K. (2015). Mikro öğretim tekniğinin Türkçe öğretmen adaylarının konuşma beceri ve kaygılarına etkisi (The effect of microteaching on pre-service Turkish language teachers' speaking skills and anxieties) (Doctoral dissertation). Gazi University, Ankara, Turkey.

Ceran, D. (2012). Türkçe öğretmeni adaylarının konuşma eğitimi dersine yönelik tutumlarının değerlendirilmesi. The Journal of Academic Social Science Studies, 5(8), 337-358.

Çiftçi, Ö. (2007). İlkögrretim 5. sınıf öğrencilerinin türkçe ögrretim programında belirtilen okuduğunu anlamayla ilgili kazanımlara ulaşma düzeyinin belirlenmesi (Doctoral dissertation). Gazi University, Ankara, Turkey.

Creswell, J. W., \& Plano Clark, V. L. (2007). Designing and conducting mixed methods research. California: Sage.

Demir, T., \& Melanlıoğlu, D. (2014). Ortaokul öğrencileri için konuşma kaygısı ölçeği: geçerlik ve güvenirlik çalışması (Speaking anxiety scale for secondary school education students: validity and reliability study). Ankara Üniversitesi Eğitim Bilimleri Fakültesi Dergisi/Ankara University, Journal of Faculty of Educational Sciences, 47(1), 103-124.

Doğan, Y. (2009). Konuşma becerisinin geliştirilmesine yönelik etkinlik önerileri (Suggested activities to improve speaking skill). Türk Eğitim Bilimleri Dergisi/The Journal of Turkish Educational Sciences, 7(1), 185-204.

Dülger, M. (2011). Konuşma becerisinin ilköğretim öğrencilerine öğretimi üzerine bir inceleme (Master's thesis). Dokuz Eylül Üniversitesi, İzmir, Turkey.

Field, A. (2013). Discovering statistics using SPSS (4th ed.). London: Sage.

Gedik, M. (2015). Siirt örnekleminde ortaöğretim öğrencilerinin konuşma kaygılarının incelenmesi (Investigation of secondary school student speech anxiety exemplified in Siirt summary). $O D U$ Sosyal Bilimler Araştırmaları Dergisi/ODU Journal of Social Sciences Research, 13, 77-93.

George, D., \& Mallery, M. (2003). Using SPSS for windows step by step: A simple guide and reference. Boston: Allyn and Bacon.

Greene, J. C., Krayder, H., \& Mayer, E. (2005). Combining qualitative and quantitative methods in social inquiry. In B. Somekh \& C. Lewin (Eds.). Research methods in the social sciences (pp. 275282). London: Sage.

Güneş, F. (2014). Konuşma öğretimi yaklaşım ve modelleri (Speech teaching approaches and models). Bartın Üniversitesi Eğitim Fakültesi Dergisi/Bartin University Journal of Faculty of Education, 3(1), 1-27.

Gürzap, C. (2010). Söz söyleme ve diksiyon [Book in Turkish]. İstanbul: Remzi Kitabevi. 
Hasırcı, S. (2018). Türkçe öğretmeni adaylarının konuşma kaygıları üzerindeki etkisi açısından akran ve öğretmen geribildirimi (Peer and teacher feedback in terms of effect on speaking anxiety of Turkish language student-teachers). Turkish Studies, 13(4), 685-706.

İşcan, A., \& Karagöz, B. (2016). Türkçe öğretmeni adaylarının konuşma kaygılarının incelenmesi (Gaziosmanpaşa Üniversitesi örneği) (A study on speech anxiety of Turkish language teacher candidates (example of Gaziosmanpaşa University). Ahi Evran Üniversitesi Kırşehir Eğitim Fakültesi Dergisi (KEFAD), 17(3), 193-206.

Kardaş, M. N. (2015). İkinci dili Türkçe olan çok dilli Türkçe öğretmeni adaylarının Türkçe konuşma kaygıları ve bu kaygılarının bazı değişkenlerle ilişkisi (Turkish speaking anxiety of the multilingual Turkish teacher candidates whose second language is Turkish and the relations of the some variables with speaking anxiety). Turkish Studies, 10(7), 541-556.

Kardaş, M. N., \& Şahin, E. (2016). Mikro öğretim yönteminin öğrencilerin Türkçe konuşma beceri ve kaygilarına etkisi (The effect of microeducation method on students' Turkish verbal skills and anxieties). Akademik Sosyal Araştırmalar Dergisi/The Journal of Academic Social Sciences, 30, 263-275.

Katrancı, M. (2014). Öğretmen adaylarının konuşma becerisine yönelik öz yeterlik algıları (Pre-service teachers' self-efficacy perception of their speaking skills). Bartın Üniversitesi Eğitim Fakültesi Dergisi/Bartin University Journal of Faculty of Education, 3(2), 174-195.

Katrancı, M., \& Kuşdemir, Y. (2015). Öğretmen adaylarının konuşma kaygılarının incelenmesi: sözlü anlatım dersine yönelik bir uygulama (Investigation of speaking anxiety of pre-service teachers: an application for speaking course). Dicle Üniversitesi Ziya Gökalp Ĕgitim Fakültesi Dergisi, 24, 415445 .

Kavruk, H., \& Deniz, E. (2015). Ortaokul öğrencilerinin konuşma kaygıları (Samsun ili örneği) (Secondary school students' speaking anxiety (the sample of Samsun)). Dil ve Edebiyat Egitimi Dergisi/Journal of Language and Literature, 3(15), 63-89.

Keşaplı, G., \& Çifci, M. (2017). Ortaokul öğrencilerinin konuşma kaygısı (Speech anxiety of elementary school students). The Journal of Academic Social Science Studies, 54, 463-484.

Kınay, İ., \& Özkan, E. (2014). Öğretmen adayları için konuşma kaygısı ölçeği geliştirilmesi: geçerlik ve güvenirlik çalışması (Developing a scale of speaking anxiety for prospective teachers: the study of validity and reliability). Turkish Studies, 9(5), 1747-1760.

Kurudayığlu, M. (2003). Konuşma eğitimi ve konuşma becerisini geliştirmeye yönelik etkinlikler. Türklük Bilimi Araştırmaları, 13, 287-309.

Lüle-Mert, E. (2015). Türkçe öğretmen adaylarının konuma kaygılarına ilişkin bir inceleme (A study on speech anxiety of Turkish language teacher candidates). Uluslararası Sosyal Araştırmalar Dergisi/The Journal of International Social Research, 8(37), 784-789.

Maviş, A. (2013). Etkili ve başarılı konuşma sanatı [Book in Turkish]. İstanbul: Yediveren.

Melanlığlu, D., \& Demir, T. (2013). Türkçe öğrenen yabancılar için konuşma kaygısı ölçeğinin Türkçe formunun geçerlik ve güvenirlik çalışması (A study on the validity and reliability of the Turkish form of speech anxiety scale for foreign Turkish learners). The Journal of Academic Social Science Studies, 6(3), 389-404. 
Okur, A., Sügümlü, Ü., \& Göçen, G. (2013). İkna edici konuşma ve karşılaştırmalı bir araştırma (Avustralya ana dili öğretimi ders materyalleri ve Türkçe örneği). Turkish Studies-International Periodical for The Languages, Literature and History of Turkish or Turkic, 8(8), 951-970.

Özbay, M. (2003). Öğretmen görüşlerine göre ilköğretim okullarında Türkçe öğretimi [Book in Turkish]. Ankara: Gölge Ofset.

Özdemir, S. (2018). Türkçe öğretmeni adaylarının konuşma kaygısını gidermede hazırlıklı konuşmaların rolü (The effect of prepared speaking on eliminating the speaking anxiety of prospective Turkish teacher). Abant İzzet Baysal Üniversitesi Ĕ̈itim Fakültesi Dergisi/ Abant İzzet Baysal University Journal of Faculty of Education, 18(1), 361-374.

Özkan, E., \& Kınay, İ. (2015). Öğretmen adaylarının konuşma kaygılarının incelenmesi (Ziya Gökalp Eğitim Fakültesi örneği) (Analysing of prospective teachers' speaking anxiety (a sample of Ziya Gökalp faculty of education). Uluslararası Türkçe Edebiyat Kültür Eğitim (TEKE) Dergisi/ International Journal of Turkish Literature Culture Education (TLCE), 4(3), 1290-1301.

Robson, C. (2001). Real world research. Oxford: Blackwell.

Sallabaş, M. E. (2012). Türkçeyi yabancı dil olarak öğrenenlerin konuşma kaygılarının değerlendirilmesi (An evaluation of speaking anxiety for learners of Turkish as a foreign language). Turkish Studies, 7(3), 2199-2218.

Sargın, M. (2006). İlköğretim öğrencilerinin konuşma becerisinin değerlendirilmesi-Muğla ili örneğinde (Master's thesis). Muğla Üniversitesi, Muğla, Turkey.

Şen, Ü. (2017). Türkçe öğretmeni adaylarinin konuşma kaygilarinin değerlendirilmesi (An analysis of speaking anxiety of Turkish teacher candidate). Uluslararası Türkoloji Araştırmaları ve Incelemeleri Dergisi, 2(2), 70-84.

Şen, Ü., \& Boylu, E. (2015). Türkçeyi yabancı dil olarak öğrenen İranlı öğrencilerin konuşma kaygılarının değerlendirilmesi (Evaluation of speaking anxiety of iranian learners learning turkish as foreign language). Mustafa Kemal Üniversitesi Sosyal Bilimler Enstitüsü Dergisi/Mustafa Kemal University Journal of Social Sciences Institute, 12(30), 13-25.

Sevim, O. (2012). Öğretmen adaylarına yönelik konuşma kaygısı ölçeği: Bir geçerlik ve güvenirlik çalışması (Speaking anxiety scale for prospective teachers: a validity and reliability study). Turkish Studies, 7(2), 927-937.

Sevim, O., \& Gedik, M. (2014). Ortaöğretim öğrencilerinin konuşma kaygılarının çeşitli değişkenler açısından incelenmesi (The investigation of speech anxiety of secondery school students according to some variables). A. U. Türkiyat Araştırmaları Enstitüsü Dergisi/Ataturk University Journal of Turkish Researches Institute, 52, 379-393.

Silverman, D. (2000). Doing qualitative research. London: Sage.

Suroğlu-Sofu, M. (2012). Öğretmen adaylarının konuşma kaygıları (Speech anxiety of junior teachers) (Master's thesis). Sakarya University, Sakarya, Turkey.

Tabachnick, B. G., \& Fidell, L. S. (2007). Using multivariate statistics (5th ed.). New York: Allyn and Bacon.

Temiz, E. (2013). Speech anxiety of music and Turkish language teacher candidates. Journal of Educational and Instructional Studies in the World, 3(2), 101-105.

Temiz, E. (2015). Pedagojik formasyon alan öğretmen adaylarının konuşma kaygıları. Turkish Studies, 10(3), 982-995. 
Topçuoğlu-Ünal F., \& Özden, M. (2012) Diksiyon ve konuşma eğitimi [Book in Turkish]. Ankara: Pegem Akademi.

Topçuoğlu-Ünal, F., \& Degeç, H. (2012). Öğretmen görüşlerine göre konuşma eğitiminde karşılaşılan sorunlar (The problems in speaking education according to teacher' judgements). The Journal of Academic Social Science Studies, 5(7), 735-750.

Topçuoğlu-Ünal, F., \& Özer, D. (2017). Ortaokul öğrencileri için konuşma becerisi tutum ölçeği: geçerlilik ve güvenirlik çalışması (Speaking skills attitude scale for middle school student: validity and reliability study). International Journal of Language Academy, 5(6), 120-131.

Tüzemen, T. (2016). Akademik çelişki tekniğinin 6. sınıf öğrencilerinin konuşma becerilerine ve konuşma kaygllarina etkisi (Effect of academic controversy technique on verbal skills and speech anxiety of 6th grade students) (Master's thesis). Yüzüncü Y1l University, Van, Turkey.

Yalçın, A. (2018). Son Bilimsel Gelişmeler Işı̆̆ında Türkçenin Öğretimi Yöntemleri [Book in Turkish]. Ankara: Akçă̆.

Yelok, V. S., \& Sallabaş, M. E. (2009). Öğretmen adaylarının sözlü anlatım dersine ve sözlü anlatıma yönelik tutumlarının değerlendirilmesi (The evaluation of the teacher candidates' attitudes towards oral speaking and oral speaking course). Türk Eğitim Bilimleri Dergisi/The Journal of Turkish Educational Sciences, 7(3), 581-606.

Yılmaz, G., \& Okur, A. (2017). Geçici eğitim merkezindeki sığınmacı ortaokul öğrencilerinin ikinci dil olarak Türkçe konuşma kaygılarının değerlendirilmesi: Sakarya örneği (Investigating Turkish as a second language speaking anxiety among refugee middle-school students at temporary education center: a case study in Sakarya). International Journal of Languages' Education and Teaching, 5(4), 504-520. 


\title{
Ortaokul öğrencilerinin konuşma kaygıları ile konuşma becerisi tutumları arasındaki ilişkinin incelenmesi ve konuşma kaygısı konusunda öğretmen görüşleri
}

\begin{abstract}
$\ddot{O} \mathbf{z}$
$\mathrm{Bu}$ araştırmada ortaokul öğrencilerin konuşma kaygısı ile konuşma becerisine yönelik tutumları arasındaki ilişki ve öğrencilerinin konuşma kaygılarının sebepleri, konuşma kaygısının gözlendiği durumlar, öğretmenlerin çözüm durumları irdelenmiştir. Araştırmada daha detaylı inceleme olanağı sağladığı için karma metod kullanılmıştır. Bu metod içerisinde açımlayıcı sıralayıcı yöntem kullanılmıştır. Araştırmanın ilk aşaması, ortaokul öğrencilerinin konuşma kaygıları ile konuşma becerisi tutumlarının arasındaki ilişkiyi belirlemek amacıyla 546 ortaokul öğrencisi ile yürütülmüştür. Araştırmanın ikinci aşaması, Türkçe öğretmenlerinin öğrencilerinde konuşma kaygısını gözlemlediği durumları, bu durumların sebeplerini ve konuşma kaygısını gidermek amacıyla yapılan etkinlikleri öğretmen görüşleriyle belirlemek amacıyla yine ilk aşamanın uygulandığı okullarda görev yapan 20 öğretmen ile görüşülmüştür. Araştırmanın veri toplama araçlarını kişisel bilgi formu, konuşma kaygısı ölçeği, konuşma becerisi tutum ölçeği ve görüşme formu oluşturmaktadır. Verilerin analizinde, IBM SPSS ve MAXQDA 12 programları kullanılmıştır. Araştırma sonuçlarına göre öğrencilerin konuşma kaygıları ve konuşma becerisi tutumları arasında negatif yönlü anlamlı bir ilişki tespit edilmiştir. Ayrıca öğretmenler, öğrencilerde konuşma kaygısını daha çok topluluk önünde konuşurken tespit ettiklerini; konuşma kaygısının sebeplerini daha çok alay edilme korkusu ve özgüven eksikliği olduğunu; konuşma kaygısını gidermek amacıyla ise daha çok uygun konuşma konusu ve ortamı oluşturma yoluna gittiklerini belirtmişlerdir.
\end{abstract}

Anahtar sözcükler: konuşma; konuşma becerisi; konuşma kaygısı; ortaokul öğrencileri

\section{AUTHOR BIODATA}

Assoc. Prof. Dr. Keziban Tekşan, Ordu University, Faculty of Education, Department of Turkish and Social Sciences Education, Turkish Language Teaching.

Assist. Prof. Dr. Hasan Hüseyin Mutlu, Ordu University, Faculty of Education, Department of Turkish and Social Sciences Education, Turkish Language Teaching.

Res. Assist. Enes Çinpolat, Ordu University, Graduate School of Social Sciences, Department of Turkish and Social Sciences Education, Turkish Teaching. 